\title{
Chemical weed control in sweet cherry peppers'
}

\author{
Esaú Orengó, Lii C. Liü and Nilsa Acin'
}

\begin{abstract}
Two herbicide experiments with sweet cherry peppers were conducted in a Fraternidad clay at Lajas Substation from 1989 to 1990 . In the first experiment, clomazone at 1.68 and $3.36 \mathrm{~kg}$ ai/ha applied pre-plant and incorporated, as well as fluazifop at 0.42 and 0.84 applied postemergence, gave excellent control of most grasses. Oxyfluorfen at $0.20 \mathrm{~kg}$ ai/ha as a pre-plant followed by bentazon at $1.12 \mathrm{~kg}$ ai/ha and fluazifop at $0.42 \mathrm{~kg}$ ai/ha also provided excellent weed control. The highest sweet cherry pepper yield was obtained with the hand-weeded control. It was then followed by oxyfluorfen af $0,20 \mathrm{~kg}$ ai/ha, then followed by bentazon + fluazifop mixture. The treatment with fluazifop at $0.42 \mathrm{~kg}$ ai/ha as a postemergence + one supplementary handweeding ranked third in yield. The above treatments did not differ significantly in yield. In the second experiment, colmazone at $2.24 \mathrm{~kg}$ ai/ha as a pre-plant, followed by three post directed application of paraquat at $0.56 \mathrm{~kg}$ ai/ha, gave the best weed control. Oxyfluorfen at $0.56 \mathrm{~kg}$ ai/ha as a pre-plant followed by bentazon at 1.12 $\mathrm{kg}$ ai/ha and fluazifop at $0.42 \mathrm{~kg}$ ai/ha mixture, also gave excellent weed control. The highest cherry pepper yield was obtained with clomazone at $2.24 \mathrm{~kg}$ ai/ha plus three applications of paraquat at $0.56 \mathrm{~kg}$ ai $/$ ha. This yield was followed by that with oxyfluorfen at $0.56 \mathrm{~kg}$ ai/ha followed by bentazone and fluazifop mixture. Napropamide at $2.24 \mathrm{~kg}$ ai/ha as a pre-plant, followed by three post directed applications of paraquat at 0.56 $\mathrm{kg}$ ai/ha, was ranked third. A good yield was also obtained with Napropamide at $2.24 \mathrm{~kg}$ ai/ha as a pre-plant followed by bentazon at 2.24 $\mathrm{kg}$ ai/ha and fluazifop at $0.42 \mathrm{~kg}$ ai/ha mixture. Yields did not differ significantly with these treatments.
\end{abstract}

\section{RESUMEN}

Control químico de las malezas en ajíes dulces

En un suelo Fraternidad de la Substación Experimental Agrícola de Lajas se realizaron dos experimentos con herbicidas en aji dulce de 1989 a 1990. En el primer experimento se encontró que clomazone a razón de 1.68 y $3.36 \mathrm{~kg}$. p.a./ha. aplicado presiembra e incorporado como el fluazifop-P a razón de 0.42 y $0.84 \mathrm{~kg}$. p.a./ha. como posemergente reprimieron las gramíneas eficazmente hasta 6 semanas después del

'Manuscript submitted to Editorial Board 26 November 1990.

${ }^{2}$ Assistant Horticulturist, Department of Horticulture.

sPlant Physiologist, Department of Crop Protection.

${ }^{4}$ Associate Chemist, Central Analytical Laboratory.

'Trade names in this publication are used only to provide specific information. Mention of a trade name does not constitute a warranty of equipment of materials by the Agricultural Experiment Station of the University of Puerto Rico, nor is this mention a statement of preference over other equipment or materials. 
trasplante. El oxyfluorfen a razón de $0.20 \mathrm{~kg}$. p.a./ha. como presiembra seguido por la mezcla bentazon a $1.12 \mathrm{~kg}$. p.a./ha. proveyó un control excelente de la mayoría de las malezas. El rendimiento más alto de aíes se obtuvo con el desyerbo a mano. A este rendimiento le seguió el del tratamiento de oxifluorfen a razón de $0.20 \mathrm{~kg}$. p.a. $/ \mathrm{ha}$. como presiembra + la mezcla de benfazon a $1.12 \mathrm{~kg}$. p.a./ha. y fluazifop-p a $0.42 \mathrm{~kg}$. p.a./ha. como posemergente. El fluazifop-P a razón de $0.42 \mathrm{~kg}$. p.a. $/ \mathrm{ha}$. + un desyerbo suplementario a mano fue tercero en rendimiento. No hubo diferencias estadísticamente significativas $(0.05)$ de probabilidad con estos tres tratamientos. En el segundo experimento, clomazone a razón de 2.24 kg. p.a./ha. como presiembra seguido por el paraquat a razón de $0.56 \mathrm{~kg}$. p.a./ha. (tres veces dirigidos) controló excelentemente la mayoría de las malezas. Oxifluorfen a razón de $0.56 \mathrm{~kg}$. p.a./ha, como presiembra seguido por la mezcla de bentazon a $2.24 \mathrm{~kg}$. p.a./ha. y fluazifop-P a $0.42 \mathrm{~kg}$. p.a./ha. como posemergente controló eficientemente. El rendimiento más alto se obfurvo con el clomazone a razón de $2.24 \mathrm{~kg}$. p.a./ha. como presiembra seguido por la aplicación dirigida de paraquat a razón de 0.56 $\mathrm{kgg} \mathrm{p.a./ha.} \mathrm{A} \mathrm{esfe} \mathrm{rendimiento} \mathrm{le} \mathrm{siguió} \mathrm{el} \mathrm{de} \mathrm{oxifluorfen} \mathrm{a} \mathrm{razón} \mathrm{de} 0.56$ kg. p.a./ha. Napropamide a razón de $2.24 \mathrm{~kg}$. p.a./ha. seguido por paraquat a $0.56 \mathrm{~kg}$. p.a./ha. ocupó el tercer lugar. Napropamide a razón de $2.24 \mathrm{~kg}$. p.a./ha. seguido por la mezcla de bentazon a $2.24 \mathrm{~kg}$. p.a./ha. y fluazifop-P a $0.42 \mathrm{~kg}$. p.a./ha. obtuvo el cuarto lugar. En estos cuatro tratamientos no hubo diferencias significativas $(P=0.05)$ en rendimiento.

\section{INTRODUCTION}

Sweet cherry pepper (Capsicum frutescens L) has been used for a long time as a condiment in Puerto Rican cooking. In recent years, both local production and imports have greatly increased. In 1987-88, local production reached $354,080 \mathrm{~kg}$ and imports, chiefly from the Dominican Republic, increased to $768,807 \mathrm{~kg}$ (1). The fact that the imports have doubled the local production suggests the existence of a great potential for increasing local production of this commodity. One of the factors limiting local production has been the high labor cost required for manual weeding in a commercial planting. The use of herbicides offers a viable altemative to the expensive manual weeding. However, there is no herbicide registered for sweet cherry peppers. The present study was thus initiated in an attempt to verify whether the herbicides currently registered for cooking peppers are effective for sweet cherry pepper production. This paper summarizes our findings obtained in 1989 and 1990 at Lajas to evaluate clomazone [2 (2-chlorophenyl) methyl -4, 4-dimethyl-3isoxazolidinone]; fluazifop-p [(R)-2-4-(5-trifluoromethyl) 2-pyridinyloxy orooanoic acid]; bentazon [(3-(1-methylethyl)-(1H)-2,1,3-benzothiadiazn$4(3 \mathrm{H})$-one 2,2-dioxide]; paraquat [1,1'-dimethyl -4-4'-bipyridinium ion], and some new herbicides for weed control in sweet cherry peppers.

There is no previous herbicide research on sweet cherry pepper in Puerto Rico. However, considerable work has been done with respect to weed control in cooking pepper, a closely related species. In 1977, Serrano-Pérez (10) reported that diphenamide at $12 \mathrm{lb} /$ acre was used for weed control in several cultivars of cooking pepper. In 1984, Liu (4) 
evaluated napropamide, diphenamide and trifluralin for weed control in pepper cultivar Cubanelle. None of these herbicides gave full-season control of weeds. In 1987, Orengo et al. (6) reported that oxyfluorfen at 1.12 $\mathrm{kg}$ ai/ha caused the highest phytotoxicity. Neither alachlor (1.68 kg ai/ha) oxadiazon, trifluralin nor pendimethalin applied 2 days before transplanting at $1.12 \mathrm{~kg}$ ai/ha was phytotoxic to peppers. The highest pepper yields were obtained in plots treated initially with glyphosate and later by either paraquat directed postemergence spray or oxadiazon pre-transplant at $1.12 \mathrm{~kg}$ ai/ha each. In the second experiment, hand-weeded check and treatments with pre-plant application of paraquat at $1.12 \mathrm{~kg}$ ai/ha, followed by oxifluorfen at $1.12 \mathrm{~kg}$ ai/ha were the high yielders. ReyesPérez et al. (7) found that the highest pepper yields, in descending order, were obtained from treatments with rice straw plus manual weeding; silver-coated black plastic plus weeding; and silver-coated black plastic alone in an integrated weed control experiment. In 1987, Semidey and Almodóvar (8) reported that there were no significant differences in pepper yield between glyphosate-treated plots (glyphosate at $0.41,0.82$ and $1.64 \%$ ) and hand-weeded plots. However, in the same trial, tomato yields were significantly reduced by use of the same concentrations of glyphosate as compared to hand-weeded control. Liu et al. (3) reported that the most profitable integrated weed management in a pepper trial was silvercoated black plastic mulch plus directed spray of paraquat at $2.34 \mathrm{~L} / \mathrm{ha}$. In 1989, Liu and Goyal $(4,5)$ evaluated quizalofop and fluazifop for grassy weed control in peppers and found both herbicides were highly effective against all grass weeds without causing any crop injury. In the same year, Semidey et al. (9) found that oxyfluorfen at $0.14 \mathrm{~kg}$ ai $/ \mathrm{ha}$, plus hand-weeding at 6 weeks, gave the highest pepper yield in one experiment. In the other experiment, they found that the highest pepper yield was obtained from the control treatment, namely pre-transplant rotavation plus two hand-weedings.

\section{MATERIALS AND METHODS}

First Experiment

The experiment was established at the Lajas substation 24 January 1989. The pre-plant application of imazethapyr (PURSUIT), ${ }^{4}$ clomazone (COMMAND), oxyfluorfen (GOAL) and napropamide (DEVRINOL) was made 24 January 1989 with an $\mathrm{R} \& \mathrm{D} \mathrm{CO}_{2}$ sprayer. A four-nozzle boom fitted with Tee Jet 8001 was used for delivering $323 \mathrm{~L} / \mathrm{ha}$ at $289 \mathrm{kPa}$. The speed of travel was calculated to be $3.9 \mathrm{~km} / \mathrm{h}$. The imazethapyr and clomazone treatments were incorporated with a rake immediately after herbicide application. The 4-week old sweet cherry pepper seedlings were transplanted to the field the following day. The first postemergence application of bentazon (BASAGRAN) and lactofen (COBRA) was made 
13 February 1989. The first application of fluazifop-P (FUSILADE) and second application of bentazon were made 27 February 1989. The second application of fluazifop-P was made 21 April 1989. The weeded check was hoe-weeded five times (14 February, $10 \mathrm{March}, 29 \mathrm{March}, 8 \mathrm{May}$ and 24 May). Fluazifop-P treatments were hand-weeded once in early March to remove broadleaf weeds only. All agronomic and pest managements followed the commercial practices used by farmers in the Lajas region (2). Marketable fruits of cherry peppers were picked three times from June to August 1989. The soil used in this experiment is a Fraternidad clay. This Vertisol soil consisted of $30 \%$ sand, $38 \%$ clay and $32 \%$ silt, $3.0 \%$ organic matter with a $\mathrm{pH}$ of 6.42 . A randomized complete block design with four replications was used in this experiment. A furrow irrigation system was used.

\section{Second Experiment}

The experiment was established on the same Fraternidad clay about one block away from the first experimental site. A randomized complete block design with four replications was used. Plots $(3.0 \mathrm{~m} \times 6.1 \mathrm{~m})$ consisted of four rows spaced $0.76 \mathrm{~m}$ apart with a distance of $31 \mathrm{~cm}$ between plants. The pre-plant applications of clomazone, napropamide, oxyfluorfen and metolachlor (DUAL) were made 20 December 1989 with the same R \& D sprayer. The same boom and nozzle tips were used again. The same Chato cultivar was transplanted the next day after the preplant sprays. Paraquat (GRAMOXONE SUPER) was sprayed three times, with a monthly interval, beginning 10 January 1990 . All paraquat applications, with plastic shield protection, were at the rate of $935 \mathrm{~L} / \mathrm{ha}$. Postemergence fluazifop-P and bentazon mixture was applied twice (10 January and $12 \mathrm{March}$ ) at the rate of $468 \mathrm{~L} / \mathrm{ha}$. The weeded checks were hoe-weeded four times (19 January, 6 February, 1 March and 21 May). The fluazifop-P + bentazon as follow-up treatment was hand-weeded once for removal of broadleaf weeds in early Feburary. All agronomic and pest managements were similar to those of the first experiment. Marketable fruits of cherry peppers were picked three times from April to June.

\section{RESULTS AND DISCUSSION}

First Experiment

The predominant weed species in experimental plots were jungle rice (Echinocloa colonum L), Johnson grass (Sorghum halepense L), goose grass (Eleusine indica L), crabgrass (Digitaria sanguinalis L), wild poinsettia (Euphorbia heterophylla L), purslane (Portulaca oleracea L), horse purslane (Trianthema portulacastrum L), pigweed (Amaranthus 
dubius Mart. ex Thell.), parthenium (Parthenium hysterophorus L), morning glory (Ipomoea tiliacea L.) and purple nutsedge (Cyperus rotundus $\mathrm{L}$ ). Of the four herbicides tested for pre-plant control of weeds, clomazone at either rate appeared to be most effective for grass control (table 1). It provided only partial control of broadleaf weed, such as wild poinsettia, but gave poor control of pigweed and purslane. Oxyfluorfen at $0.20 \mathrm{~kg}$ ai/ha gave only fair control of both broadleaf weeds and grasses. Napropamide at $2.24 \mathrm{~kg}$ ai/ha rate gave poor control of broad leaf weeds. However, when these pre-plant herbicides were followed by postemergence application of either a bentazon or a bentazon + fluazifop-P mixture, weed control improved considerably. Fluazifop at either rate gave excellent control of grasses but was ineffective against all broadleaf weeds. Lactofen, on the other hand, controlled broadleaf weeds but was ineffective against grasses. Imazethapyr at either rate gave excellent control of broadleaf weeds but was weak on grass control. The most severe crop injury occurred with lactofen treatments. Lactofen-treated pepper plants died completely within 2 weeks of herbicide application. Imazethapyr also caused considerable crop injury, the affected crop finally died by weed suffocation. The postemergence application of bentazon caused slight leaf burning, which was later outgrown. None of the fluazifop-P treatments caused any apparent crop injury.

The highest cherry pepper yield was obtained with the hand-weeded check (table 1). This treatment did not differ significantly in yield with oxyfluorfen at $0.20 \mathrm{~kg}$ ai/ha followed by bentazon at $1.12 \mathrm{~kg}$ ai/ha + fluazifop at $0.42 \mathrm{~kg}$ ai $/ \mathrm{ha}$ treatment and fluazifop alone at $0.42 \mathrm{~kg}$ ai $/ \mathrm{h}+$ one supplementary hand weeding treatment. All other herbicide treatments yielded significantly less than the hand-weeded check.

\section{Second Experiment}

The weed species in plots were similar to those of the first experiment with a greater prevalence of Johnson grass and parthenium species. Clomazone at $2.24 \mathrm{~kg}$ ai/ha, followed by three post directed applications of paraquat at $0.42 \mathrm{~kg}$ ai/ha, effectively controlled most of weeds with the exception of parthenium (table 2). Parthenium in the border rows was effectively controlled by glyphosate at $1 \%$ but not with paraquat at the indicated rate. Napropamide at $2.24 \mathrm{~kg}$ ai/ha, followed by either fluazifop-P and bentazon mixture or by paraquat at $0.56 \mathrm{~kg}$ ai/ha gave acceptable weed control. Oxyfluorfen alone at either rate gave good weed control at the first evaluation date but was poor as time progressed. Oxyfluorfen at $0.56 \mathrm{~kg}$ ai/ha, followed by either paraquat at $0.56 \mathrm{~kg}$ ai/ha or by fluazifop-P + bentazon mixture also gave acceptable weed control. The same was true with metolachlor at either rate followed by paraquat at $0.56 \mathrm{~kg}$ ai/ha treatments. Oxyfluorfen at $1.12 \mathrm{~kg}$ ai $/ \mathrm{ha}$ as well as 
TABLE 1.-Effect of herbicide treatment on weed control, phytptoxicity, and yield of sweet cherry pepper (1988-89)

\begin{tabular}{|c|c|c|c|c|c|c|c|c|}
\hline & \multirow[b]{3}{*}{ Treatment } & \multicolumn{4}{|c|}{ Weed control' } & & & \\
\hline & & \multirow{2}{*}{$\begin{array}{l}\text { Broadleaf } \\
2-27-89\end{array}$} & \multirow{2}{*}{$\begin{array}{l}\text { Grasses } \\
2-27-89\end{array}$} & \multirow{2}{*}{$\begin{array}{l}\text { Broadleaf } \\
3-27-89\end{array}$} & \multirow{2}{*}{$\begin{array}{l}\text { Grasses } \\
3-27-89\end{array}$} & \multicolumn{2}{|c|}{ Phytoxocity² } & \multirow[b]{2}{*}{ Yield $^{3}$} \\
\hline & & & & & & $2-27-89$ & $3-27-89$ & \\
\hline & & & $\%$ & $\%$ & $\%$ & $\%$ & & kg/ha \\
\hline 1. & Imazethapyr $0.10 \mathrm{kgai} / \mathrm{ha}$ (PPI) & 83 & 15 & 70 & 0 & 2.8 & 3.4 & 0 \\
\hline 2. & Imazethapyr $0.20 \mathrm{~kg} \mathrm{ai} / \mathrm{ha}(\mathrm{PPI})$ & 88 & 20 & 75 & 0 & 3.0 & 3.8 & $0 \quad d$ \\
\hline 3. & Clomazone $1.68 \mathrm{~kg}$ ai/ha (PPI) & 50 & 94 & 28 & 75 & 0 & 3.0 & $2,329 \mathrm{~cd}$ \\
\hline 4. & Clomazone $3.36 \mathrm{~kg}$ ai/ha (PPI) & 59 & 96 & 30 & 85 & 0 & 0 & $4,272 \mathrm{~cd}$ \\
\hline 5. & Oxyfluorfen $0.20 \mathrm{~kg}$ ai/ha & 28 & 20 & 15 & 3 & 0 & 0 & 0 \\
\hline 6. & $\begin{array}{l}\text { Oxyfluorfen } 0.20 \mathrm{~kg} \text { ai/ha } \\
\text { + Bentazon } 1.12 \mathrm{~kg} \text { ai/ha } \\
\text { + Fluazifop } 0.42 \mathrm{~kg} \text { ai/ha }\end{array}$ & 78 & 30 & 65 & 100 & 2.5 & 1.0 & $5,239 \mathrm{ab}$ \\
\hline 7. & $\begin{array}{l}\text { Oxyfluorfen } 0.02 \mathrm{~kg} \text { ai/ha } \\
+ \text { Bentazon } 2.24 \mathrm{~kg} \text { ai/ha }\end{array}$ & 78 & 41 & 68 & 0 & 3.3 & 1.5 & d \\
\hline 8. & Napropamide $2.24 \mathrm{ka}$ ai/ha & 20 & 25 & 10 & 15 & 0 & 0 & $122 \mathrm{~d}$ \\
\hline 9. & $\begin{array}{l}\text { Napropamide } 2.24 \mathrm{~kg} \text { ai/ha } \\
+ \text { Bentazon } 1.12 \mathrm{~kg} \text { ai } / \mathrm{ha}\end{array}$ & 73 & 43 & 63 & 10 & 2.3 & 0 & $31 \mathrm{~d}$ \\
\hline 10. & $\begin{array}{l}\text { Napropamide } 2.24 \mathrm{~kg} \mathrm{ai} / \mathrm{ha} \\
\text { + Bentazon } 2.24 \mathrm{~kg} \mathrm{ai} / \mathrm{ha}\end{array}$ & 74 & 28 & 65 & 10 & 2.5 & 0 & $224 \mathrm{~d}$ \\
\hline 11. & Weeded check & 96 & 96 & 93 & 93. & 0 & 0 & $7,548 \mathrm{a}$ \\
\hline 12. & Non-weeded check & 0 & 0 & 0 & 0 & 0 & 0 & $265 d$ \\
\hline 13. & Fluazifop $0.42 \mathrm{~kg}$ ai/ha & 0 & 100 & 0 & 90 & 0 & 0 & $5,116 \mathrm{ab}$ \\
\hline 14. & Fluazifop 0.84 & 0 & 100 & 0 & 90 & 0 & 0 & $4,018 \mathrm{bc}$ \\
\hline 15. & $\begin{array}{l}\text { Napropamide } 2.24 \mathrm{~kg} \text { ai/ha } \\
\text { + Lactofen } 0.22 \mathrm{~kg} \text { ai/ha }\end{array}$ & 100 & 0 & 90 & 0 & 5.0 & 5.0 & $0 \quad d$ \\
\hline 16. & Napropamide $2.24 \mathrm{~kg}$ ai/ha & 100 & 0 & 90 & 0 & 5.0 & 5.0 & 0 \\
\hline
\end{tabular}

${ }^{1}$ Weed control ratings are based on $0-100 \% ; 0=$ no control; $100=$ perfect control.

${ }^{2}$ Phytotoxicity evaluations are based on 0 to 5 scale. $0=$ no injury; $5.0=$ complete stand reduction.

${ }^{3}$ Means bearing the same letter or letters do not differ significantly at the 0.05 probability level. 
TABLE 2.-Effect of herbicide treatment on weed control, phytptoxicity, and yield of sweet cherry pepper (1989-90)

\begin{tabular}{|c|c|c|c|c|c|c|c|c|}
\hline & \multirow[b]{3}{*}{ Treatment } & \multicolumn{4}{|c|}{ Weed control ${ }^{2}$} & & & \multirow[b]{3}{*}{ Yield $^{\mathfrak{3}}$} \\
\hline & & \multirow{2}{*}{$\begin{array}{l}\text { Broadleaf } \\
\text { weeds } \\
1-10-90\end{array}$} & \multirow{2}{*}{$\begin{array}{l}\text { Grasses } \\
1-10-90\end{array}$} & \multirow{2}{*}{$\begin{array}{l}\text { Broadleaf } \\
\text { weeds } \\
3-5-90\end{array}$} & \multirow{2}{*}{$\begin{array}{c}\text { Grasses } \\
3-5-90\end{array}$} & \multicolumn{2}{|c|}{ Phytotoxicity ${ }^{2}$} & \\
\hline & & & & & & $1-10-90$ & $3-5-90$ & \\
\hline & & $\%$ & $\%$ & $\%$ & $\%$ & & & $\mathrm{~kg} / \mathrm{ha}$ \\
\hline 1. & $\begin{array}{l}\text { Clomazone } 1.12 \mathrm{~kg} \mathrm{ai} / \mathrm{ha} \\
+ \text { paraquat } 0.56 \mathrm{~kg} \text { ai } / \mathrm{kg}\end{array}$ & 40 & 85 & 75 & 90 & & 1.5 & $2,841 \mathrm{ab}$ \\
\hline 2. & $\begin{array}{l}\text { Clomazone } 2.24 \mathrm{~kg} \mathrm{ai} / \mathrm{ha} \\
+ \text { paraquat } 0.56 \mathrm{~kg} \text { ai } / \mathrm{ha}\end{array}$ & 53 & 95 & 88 & 95 & 0 & 1.5 & $4,117 \mathrm{ab}$ \\
\hline 3. & $\begin{array}{l}\text { Napropamide } 2.24 \mathrm{~kg} \text { ai/ha } \\
+ \text { paraquat } 0.56 \mathrm{~kg} \text { ai/ha }\end{array}$ & 55 & 75 & 40 & 80 & 0 & 0 & $2,989 \mathrm{ab}$ \\
\hline 4. & $\begin{array}{l}\text { Napropamide } 2.24 \mathrm{~kg} \text { ai/ha } \\
\text { + paraquat } 0.56 \mathrm{~kg} \text { ai/ha }\end{array}$ & 58 & 79 & 66 & 90 & 0 & 1.5 & $3,389 a b$ \\
\hline 5. & Oxyfluorfen $0.56 \mathrm{~kg}$ ai $/ \mathrm{ha}$ & 81 & 85 & 50 & 45 & 0 & 0 & $2,285 \mathrm{~b}$ \\
\hline 6. & Oxyfluorfen $1.12 \mathrm{~kg}$ ai/ha & 93 & 90 & 65 & 55 & 2.0 & 1.0 & $2,224 \mathrm{~b}$ \\
\hline 7. & $\begin{array}{l}\text { Oxyfluorfen } 0.56 \mathrm{~kg} \text { ai/ha } \\
+ \text { paraquat } 0.56 \mathrm{~kg} \text { ai/ha }\end{array}$ & 75 & 80 & 55 & 85 & & 1.5 & $2,605 a b$ \\
\hline 8. & $\begin{array}{l}\text { Oxyfluorfen } 0.56 \mathrm{ka} \mathrm{ai} / \mathrm{ha} \\
\text { + fluazifop } 0.42 \mathrm{~kg} \text { ai/ha } \\
\text { + bentazon } 2.24 \mathrm{~kg} \text { ai/ha }\end{array}$ & 78 & 79 & 66 & 85 & 0 & 0 & $3,689 a b$ \\
\hline 9. & $\begin{array}{l}\text { Metolachlor } 2.24 \mathrm{~kg} \text { ai } / \mathrm{ha} \\
+ \text { paraquat } 0.56 \mathrm{~kg} \text { ai } / \mathrm{ha}\end{array}$ & 59 & 88 & 65 & 90 & 0 & 1.5 & $2,026 \mathrm{~b}$ \\
\hline 10. & $\begin{array}{l}\text { Metolachlor } 4.48 \mathrm{~kg} \text { ai/ha } \\
\text { + paraquat } 0.56 \mathrm{~kg} \text { ai/ha }\end{array}$ & 63 & 90 & 71 & 93 & 1.5 & 1.5 & $2,624 \mathrm{ab}$ \\
\hline 11. & Weeded check & - & - & 95 & 95 & 0 & 0 & $3,208 \mathrm{ab}$ \\
\hline 12. & Non-weeded check & 0 & 0 & 0 & 0 & 0 & 0 & $175 \mathrm{c}$ \\
\hline
\end{tabular}

'Weed control ratings are based on $0-100 \% ; 0=$ no control; $100=$ perfect control.

${ }^{2}$ Phytotoxicity evaluations are based on 0 to 5 scale. $0=$ no injury; $5.0=$ complete stand reduction.

${ }^{3}$ Means bearing the same letter or letters do not differ significantly at the 0.05 probability level. 
metolachlor at $4.48 \mathrm{~kg}$ ai/ha caused a slight crop injury at the first evaluation date, but that crop later recovered completely. Paraquat at $0.56 \mathrm{~kg}$ ai/ha as a follow-up treatment also caused slight injury that the crop later outgrew. The injury caused by paraquat was mainly by drift effect during the application time; the crop recovered rapidly.

The highest cherry pepper yield was obtained with clomazone at 2.24 $\mathrm{kg}$ ai/ha followed by paraquat at $0.56 \mathrm{~kg}$ ai/ha (three times) treatment (table 2). Next highest yield was that with oxyfluorfen at $0.56 \mathrm{~kg}$ ai $/ \mathrm{ha}$ plus fluazifop-P and bentazon mixture (two times) treatment. Third in yield was the treatment with napropamide at $2.24 \mathrm{~kg}$ ai/ha followed by paraquat at $0.56 \mathrm{~kg}$ ai/ha (three times). These three treatments did not differ significantly in yield from all other treatments with the exception of the non-weeded check.

Clomazone and fluazifop-P have shown great promise in weed control in cooking peppers in Puerto Rico (5). The results of this study confirm their great potential for weed control in cherry peppers. Residue samples of both herbicides were collected and sent to IR-4 Pesticide Laboratory for analysis. Since both herbicides are excellent grass killers, they would solve our grassy weed infestation problem for cherry pepper farmers. Both herbicides could be used in conjunction with paraquat to achieve a broader spectrum of weed control as soon as their registrations are granted.

\section{LITERATURE CITED}

1. Anonymous, 1988. Facts and Figures on Puerto Rico's Agriculture. 1987-88. Dept. Agric. Office of Agricultural Statistics, Santurce, P. R.

2. Liu, L. C., 1984. Control de malezas en tomates y pimientos. Revista del Colegio de Agrónomos de Puerto Rico. P. 11 y 27.

3. Liu, L. C., M. Antoni-Padilla, M. R. Goyal and J. González-Ibánez. 1987. Integrated weed managemnet in transplanted tomatoes and peppers under drip irrigation. $J$. Agric. Univ. P. R. 71 (4): 349-58.

4. Liu, L. C. and M. R. Goyal, 1989. Selective herbicides to control grasses in transplanted tomatoes and peppers. J. Agric. Univ. P. R. 73 (3): 231-37.

5. Liu, L. C., 1989. Annual Progress Report of Project H-173, Agric. Exp. Stn., Univ. P. R.

6. Orengo-Santiago, E., N. Semidey and L. Almodóvar-Vega, 1987. Influence of glyphosate and paraquat pre-transplant treatment on weed control and pepper yields. $J$. Agric. Univ. P. R. 71 (1):66-73.

7. Reyes-Pérez, L. A., L. C. Liu and L. Almodóvar-Vega, 1986. Integrated weed control in transplanted peppers. Proc. 22th Annual meeting of the Caribbean Food Crops Society 22: 324-30.

8. Semidey, N. and L. Almodóvar-Vega, 1987. Glyphosate on tomato and sweet pepper yields. J. Agric. Univ. P. R. 71 (2): 209-16.

9. - N., E. Caraballo and N. Acin, 1989. Broadleaf weed control in peppers with herbicides applied pre-transplant. J. Agric. Univ. P. R. 73 (1): 67-73.

10. Serrano-Pérez, A. C., 1977. Yield of sweet peppers (Capsicum annuum L.) cultivars in northwestern Puerto Rico. J. Agric. Univ. P. R. 61 (1): 90-99. 